\title{
Related Party Transactions, Family Ownership, and Earnings Management in Indonesia
}

\author{
Levina Ulfa Subastian ${ }^{1 *}$, Ari Kuncara Widagdo², Doddy Setiawan ${ }^{3}$ \\ 1,2,3 Program of Magister Accounting, Faculty of Economics and Business, Universitas Sebelas \\ Maret, Surakarta, Indonesia \\ *Corresponding Author: levinasubastian@student.uns.ac.id
}

\begin{abstract}
The purpose of earnings management practice is to reach the profit goals the company wants to achieve. Therefore, this study aims to determine the relationship between related party transactions and earnings management in Indonesia by balanced panel data from consumer goods companies listed on the Indonesia Stock Exchange (IDX) from 2017 to 2019. The number of samples used in this study was 102 firm-year observations. The results showed that related party transactions positively and significantly improved corporate earnings management, with discretionary accrual as a proxy. The presence of family ownership strengthens the relationship between related party transactions and earnings management. Also, it shows that the control variable: public accountant from BIG4, company size, company losses, and ROA affect accrual earnings management. The leverage does not affect accrual earnings management. The study result indicates that family business ownership encourages an entrenchment effect that is detrimental to the company. It is carried out through related party transactions then manipulated by using accrual earnings management practices.
\end{abstract}

Keywords: discretionary accruals; earnings management; family ownership structure; related party transaction

JEL Classification: G32; M41

\section{INTRODUCTION}

As a measure of the company's condition, the financial report provides an impetus for the company to carry out earnings management. Management has a right to choose accounting policies or specific actions that can affect its revenue, which will affect the number of profit goals (Scott \& O'Brien, 1997; Penman, 2013). Management made several changes in the appraisal process and prepared financial statement components that would change its profits, intending to mislead shareholders or potential investors toward its performance (Healy \& Wahlen, 1999). In line with these conditions, earnings management 
is also known as earnings manipulation, and it is carried out both outside and inside the boundaries of the rules determined by the Generally Accepted Accounting Principles (GAAP) (Dechow \& Skinner, 2000).

In Indonesia, the practice of earnings management is considered to lead to detrimental earnings management for some parties or opportunistic earnings management, compared to efficient earnings management (Azizah, 2017). Efficient earnings management is carried out to assist companies in dealing with unexpected conditions in the future. In contrast, opportunistic earnings management is an advanced earnings management carried out by management for its interests, such as incentives for achieving targets (Scott \& O'Brien, 1997). In Indonesia, there have been many cases related to company earnings management, such as PT Kimia Farma in 2002 and PT Indofarma in 2004 were proven to increase companies' revenue and present net income higher than the actual (Muda et al., 2018). Besides, In 2015, PT Garuda Indonesia also committed violations that affected the number of company profits and were found guilty of harming various interested parties (Mardjono et al., 2020). One way to manage reported earnings is through transactions with related parties (Maigoshi et al., 2016), which affect earnings quality (Rahmat et al., 2020) as has been done in Italy, which uses revenue transactions with related parties to manage earnings (Marchini et al., 2018b).

In Indonesia, related party transaction is a way to increase management's gain and control shareholders because the regulations governing public investors' protection are still weak (Habib et al., 2017). Also, related party transactions can be detrimental to minority shareholders due to tunneling (a conflict between controlling shareholders and non-controlling interest due to differences in the ownership structure) by the controlling shareholder (Kharista et al., 2020). Earnings management carried out through related party transactions is considered to have the objective of maximizing personal interest by transferring a certain amount of company funds to affiliates for particular purposes and then manipulate it with earnings management actions (Kuan et al., 2010).

Opportunistic earnings management behavior is also affected by the inequality of information held by internal parties (asymmetry information) the company management with other parties, such as minority shareholders or external parties as users of financial reports (Mardjono et al., 2020). It creates a conflict of interest in the relationship between company management and minority shareholders (Jensen \& Meckling, 1976). When management practices earnings management through related party transactions without making adequate disclosures or not under regulations about how an entity should disclose the related party transactions.

The existence of problems related to the related party transactions to maximize profits through earnings management practices is considered more robust when decisions related to these transactions are influenced by controlling shareholders who are part of the company owners. Family companies are proven to carry out higher earnings management (Paiva et al., 2019) compared to non-family companies. A lack of supervision makes the company expropriate the wealth of minority shareholders for their interest (Lisboa, 2016).

In Indonesia, most companies have a concentrated ownership structure, especially family ownership. PwC (2014) stated that 95\% of businesses in Indonesia are family businesses so that their role as controlling shareholders is quite significant in making decisions that will affect the company. Also, family ownership as a controller 
can choose their relatives or families to hold strategic positions in the company (Setiawan et al., 2016), making it easier to carry out opportunistic transactions. High family involvement in the company's business can provide an opportunity for a family to monopolize the ownership and management of the company (Paiva et al., 2016), which could endanger the company or minority shareholders.

Previous research related to the effect of related party transactions on earnings management practices is quite a lot (Gordon \& Henry, 2005; Aharony et al., 2010; Kuan et al., 2010; Chen et al., 2011; Wong et al., 2015; Maigoshi et al., 2016; Marchini et al., 2018b). Gordon \& Henry (2005) show a relationship between certain related party transactions on companies' earnings management. El-Helaly et al. (2018) stated that companies that carry out related party transactions tend not to be involved in real earnings management practices. But, El-Helaly (2016) concluded that companies that carry out related party transactions do not always manipulate company profits, decreasing the companies' accounting quality.

The inconsistency of those researches about related party transactions on earnings management encourages other research to added several moderating variables such as audit quality (El-Helaly et al., 2018), women as part of the audit committee board of directors (Jalan et al., 2020), mechanism of good corporate governance (Mita \& Utama, 2015; Limanto \& Herusetya, 2017; Marchini et al., 2018a), and family ownership structures or corporate, institutional ownership structures in Malaysia and Jordan (Haji-Abdullah \& Wan-Hussin, 2015; Alhadab et al., 2020).

This study aims to examine the effect of transactions with related parties on earnings management carried out by companies, especially consumer goods companies in Indonesia. This research will focus on the consumer goods industry sector listed in the Indonesia Stock Exchange 2017-2019 because it has a higher operational activity than other manufacturing sub-sectors (Siregar et al., 2018). Thus, its management could manage company activities and maximize profitability with earnings management practices, increasing its value. However, it is likely to decrease afterward because the relevance of the company's value decreases (Shan, 2015).

\section{HYPOTHESIS DEVELOPMENT}

\section{Related Party Transactions and Earnings Management}

Company transactions with related parties can influence opportunistic behavior by company management to increase their interests. Rahmat et al. (2020) state that related party transactions are used by management and majority shareholders opportunistically to reduce earnings quality; it is easier to do if these companies are in a country with weak investment protection regulations. According to the agency theory, asymmetry information increases the possibility of opportunistic behavior in maximizing the utility of earnings management. This is due to the company's external parties' ignorance regarding all transactions carried out by the company's internal parties, such as debt agreements or political costs (Mardjono et al., 2020).

The characteristic of companies in Indonesia, where regulations related to the protection of minority shareholders or public shareholders are still weak (Habib et al., 2017), provides opportunities for management to take advantage of abusive related party transactions. The number of related party transactions will affect the disclosure of the company's net income if it is carried out to expropriate the wealth of minority shareholders. 
It encourages management to practice earnings management so that the company's net income looks pleasing, even though it is not under the actual conditions. Although ElHelaly et al. (2018) revealed that there is no systematic relationship between related party transactions and accrual earnings management, there is a possibility that related party transactions are used as a substitute for real earnings management. Limanto \& Herusetya (2017) stated that related party transactions carried out by companies escalate the earnings management practice in Indonesia. However, other research in Indonesia shows that related party transactions do not affect earnings management practices because they may be used appropriately and efficiently (Suryani et al., 2019).

Research conducted by Haji-Abdullah \& Wan-Hussin (2015) also shows that related party transactions are used as a tool to expropriate the wealth of minority shareholders and proven improve earnings management through real activities. Likewise, in Italy, Marchini et al. (2018b) revealed that revenue transactions from related parties are more widely used to manage earnings than other types of related transactions. Based on the existing description, the hypothesis in this study is as follows.

$\mathrm{H}_{1}$ : Related party transactions have a positive effect on earnings management practice

\section{Family Ownership, Related Party Transactions, and Earnings Management}

Family ownership is a shareholder structure that is commonly found in Indonesia because more than half of the shareholders in public companies in Indonesia are family shareholders. A large percentage of family ownership can be interpreted as the controlling shareholder. Therefore, family ownership can influence applicable policies and decisions, including decisions related to company transactions with related parties.

Related party transactions can be seen as transactions that provide benefits in meeting a company's needs at low costs to meet its specific needs (Marchini et al., 2018b). However, since more information is owned by family ownership as controlling shareholder, related party transactions can be used to expropriate minority shareholders resources due to transfer pricing activities (Marchini et al., 2019). Moreover, the influences also encourage the company to manage earnings on the company's financial statements to provide results according to the desired goals. Chi et al. (2015) show that in Taiwan, the level of earning management in family firms is higher than non-family firms, which resulted in lower earnings quality.

Other studies conducted by Haji-Abdullah \& Wan-Hussin (2015) revealed that family ownership weakens earnings management level through related party transactions in Malaysia. In Indonesia, the interaction between accrual earnings management and family companies strengthens earnings management, which can affect the company's future performance (Suprianto \& Setiawan, 2018). Likewise, in India and China, family companies are proven to influence earnings management practices in their companies (Avabruth \& Saravanan, 2018; Tai, 2017). Furthermore, Paiva et al. (2019) stated that family companies carry out earnings management at a higher level than non-family companies unless an analyst can control the family control over the company's operations. Based on the existing description, the hypothesis in this study is as follows.

$\mathrm{H}_{2}$ : Family ownership has a positive effect on earnings management practice

$\mathrm{H}_{3}$ : Family ownership strengthens the positive relationship between related party transactions and earnings management practice 


\section{METHOD, DATA, AND ANALYSIS}

\section{Research Methods}

In this study, the data population used is sourced from the annual reports of manufacturing-based companies that provide consumer goods and are listed on the Indonesia Stock Exchange (IDX) in 2017-2019. The data samples obtained were 34 companies, and 102 observations could be tested.

Earnings management used in this study uses accrual earnings management proxies. Accrual earnings management (DAC) is calculated using the modified Jones model (Dechow et al., 1995). Related party transactions are calculated from the company's total related party transactions divided by total assets owned. The moderating variable used is

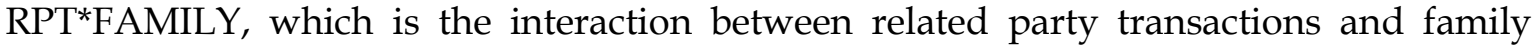
ownership. Family ownership is calculated by the total percentage of family ownership in the company's capital structure. This study also employs some control variables, namely, auditor firm BIG4, company's size (FIRM SIZE), company's ability to cover debt owned by assets (LEVERAGE), company's earnings (LOSS), and the level of company profitability (ROA). Further variable descriptions are presented in Table 1.

Table 1. Variable Description

\begin{tabular}{|c|c|c|}
\hline Variable & Description & Source \\
\hline $\mathrm{DAC}$ & Modified Jones Model & Dechow et al. (1995) and Kuan et al. (2010) \\
\hline RPT & $\begin{array}{l}\text { Total related party transactions of } \\
\text { the company divided by total } \\
\text { assets owned }\end{array}$ & Hasnan et al. (2016) \\
\hline FAMILY & $\begin{array}{l}\text { If the percentage of ownership by } \\
\text { the family is more than } 20 \% \text {, then } 1 \\
\text { and } 0 \text { are otherwise }\end{array}$ & Haji-Abdullah \& Wan-Hussin (2015) \\
\hline RPT*FAMILY & $\begin{array}{l}\text { The interaction between the related } \\
\text { party transaction variables with the } \\
\text { percentage of family ownership }\end{array}$ & \\
\hline BIG4 & $\begin{array}{l}\text { If KAP is BIG4, then } 1 \text { and } 0 \text { are } \\
\text { otherwise }\end{array}$ & El-Helaly (2018) \\
\hline FIRM SIZE & Natural logarithm of total assets & Chen et al. (2011) \\
\hline LEVERAGE & $\begin{array}{l}\text { Total liabilities divided by total } \\
\text { assets }\end{array}$ & Kuan et al. (2010) \\
\hline LOSS & $\begin{array}{l}\text { If the company incurred a loss in } \\
\text { year } t \text {, then } 1 \text { and } 0 \text { vice versa }\end{array}$ & Marchini et al.(2018b) \\
\hline ROA & $\begin{array}{l}\text { Net income after tax divided by } \\
\text { total assets }\end{array}$ & Kuan et al. (2010) \\
\hline
\end{tabular}

\section{Hypothesis Testing Model}

To test the hypotheses formulated, the researcher conducted a panel data regression analysis. There are three equations to examines the hypotheses in this research. The existing regression model tests hypothesis 1 from the effect of related party transactions on corporate earnings management practices and the control variables described as following equation 1. 


$$
\begin{aligned}
E M= & \alpha+\beta_{1} R P T+\beta_{2} B I G 4+\beta_{3} \text { FIRM SIZE }+\beta_{4} L E V E R A G E+\beta_{5} L O S S+ \\
& \beta_{6} R O A+\varepsilon
\end{aligned}
$$

Furthermore, to find out whether the variable family ownership independently affects earnings management. Likewise, to determine the interaction between RPT * FAMILY on earnings management, a regression model is used as following equations 2 and 3.

$$
\begin{aligned}
& E M=\alpha+\beta_{1} R P T+\beta_{2} \text { FAMILY }+\beta_{3} \text { BIG }+\beta_{4} \text { FIRM SIZE }+\beta_{5} L E V E R A G E+ \\
& \beta_{6} L O S S+\beta_{7} R O A+\varepsilon \\
& \text { EM }=\alpha+\beta_{1} R P T+\beta_{2} \text { FAMILY }+\beta_{3} R P T * \text { FAMILY }+\beta_{4} B I G+\beta_{5} \text { FIRM SIZE }+ \\
& \beta_{6} L E V E R A G E+\beta_{7} L O S S+\beta_{8} R O E+\varepsilon
\end{aligned}
$$

\section{RESULTS AND DISCUSSION}

\section{Descriptive Analysis}

As 102 observations data were tested, Table 2 shows the descriptive statistics of all the variables used in this research. It includes the mean, maximum, minimum, standard deviation of all variables used and each dummy variable's frequency.

Table 2. Descriptive statistics

\begin{tabular}{lrrrrrr}
\hline \multicolumn{1}{c}{ Variable } & Mean & Maximum & Minimum & Std. Dev. & N & Frequency \\
\hline DAC & -0.001 & 1.200 & -0.203 & 0.144 & 102 & \\
RPT & 0.453 & 6.097 & 0.000 & 0.992 & 102 & \\
FAMILY & 0.667 & 1.000 & 0.000 & 0.474 & 102 & 69 \\
$\quad$ More than 20\% & & & & & & 33 \\
$\quad$ Less than 20\% & & & & & & 44 \\
BIG4 & 0.431 & 1.000 & 0.000 & 0.498 & 102 & 58 \\
$\quad$ Big 4 & & & & & & \\
$\quad$ Non-Big 4 & 14.846 & 18.385 & 11.915 & 1.624 & 102 & \\
FIRM SIZE & 0.396 & 0.770 & 0.065 & 0.181 & 102 & \\
LEVERAGE & 0.206 & 1.000 & 0.000 & 0.406 & 102 & \\
LOSS & & & & & & \\
$\quad$ Loss & & & & & & \\
$\quad$ Gain & 0.095 & 0.921 & -0.176 & 0.146 & 102 & \\
ROA & & & & & & \\
\hline Notes:Fam & & & & & & \\
\hline
\end{tabular}

Notes: Family is categorized as 1 if it has a share percentage of more than $20 \%$, and 0 if the opposite is true; BIG4 is categorized as 1 if audited by BIG4, and 0 if the opposite; Loss is categorized as 1 if the company experiences a loss, and 0 if the other way around; DAC = Accruals earnings management; RPT = Related Part Transactions; FAMILY = Family ownership structures; BIG4 = Audit firm; FIRM SIZE = company's size; LEVERAGE = company's ability to cover debt owned by assets; LOSS = company's earnings; ROA = the level of company profitability.

Earnings management using discretionary accrual (DAC) proxies in this study has an average of -0.001 with a maximum and minimum value of 1.200 and -0.203 , respectively. DAC with a maximum value of 1.200 indicates that the level of earnings management practiced is high, around $120 \%$ of the actual profit. It indicates that the sample companies 
in this study carry out earnings management practices in two directions by maximizing or minimizing the company's profit to achieve specific goals.

Transactions conducted by companies with their affiliations (RPT) have an average value of 0.453 with a maximum and minimum value of 6.097 and 0.000 , respectively. It shows that the average value of the company's related party transactions is worth $45.3 \%$ compared to the company's total assets. However, some do not make transactions with related parties in specific years. Family ownership (FAMILY) has an average value of 0.667 with a maximum and minimum value of 1 and 0 , respectively, because it is a dummy variable. Approximately $66.7 \%$ indicated that such companies' families or founders still dominate a majority percentage of Indonesia's capital ownership.

\section{Correlation Analysis}

The correlation test is carried out to determine the relationship between the variables in the study and see whether there is multicollinearity in the research model. Table 3 shows that related party transactions are negatively correlated with earnings management, but not significant and family ownership are significantly and negatively correlated with earnings management. Although these correlations do not support expected directions in the hypotheses, the research model does not have multicollinearity problems because there are no variables related to each other that exceed the limit of 0.80 . From the table, the highest correlations are 0.520 , between ROA and earnings management.

Table 3. Correlation between Research Variables

\begin{tabular}{|c|c|c|c|c|c|c|c|c|}
\hline Variable & DAC & RPT & FAMILY & BIG4 & FIRM SIZE & LEVERAGE & LOSS & ROA \\
\hline DAC & 1 & & & & & & & \\
\hline RPT & -0.117 & 1 & & & & & & \\
\hline FAMILY & $-0.220^{* *}$ & $0.217^{\star *}$ & 1 & & & & & \\
\hline BIG4 & 0.053 & $0.216^{* *}$ & -0.056 & 1 & & & & \\
\hline FIRM SIZE & -0.018 & -0.016 & -0.073 & $0.452^{*}$ & 1 & & & \\
\hline LEVERAGE & 0.090 & -0.146 & $-0.219^{\star *}$ & $-0.188^{* * *}$ & 0.013 & 1 & & \\
\hline LOSS & -0.135 & -0.116 & 0.051 & $-0.346^{*}$ & $-0.410^{*}$ & $0.325^{*}$ & 1 & \\
\hline ROA & $0.520^{*}$ & 0.001 & $-0.311^{*}$ & $0.503^{*}$ & $0.306^{*}$ & -0.076 & $-0.478^{*}$ & 1 \\
\hline
\end{tabular}

\section{Regression Analysis}

Table 4 shows the results of panel data regression testing using a research model with fixed effects. The regression results show that related party transactions have a significant positive effect on accrual earnings management. This test supports hypothesis 1 , which indicates that related party transactions lead to transactions that improve accrual earnings management practices. This result is consistent with various previous studies, which show that related party transactions have a significant positive effect on corporate earnings management practices (Haji-Abdullah \& Wan-Hussin, 2015; Limanto \& Herusetya, 2017; Rahmat et al., 2020). 
Table 4. FEM Regression Results (EGLS)

\begin{tabular}{lcccc}
\hline \multirow{2}{*}{ Variable } & Exp. & \multicolumn{3}{c}{ DAC } \\
\cline { 3 - 5 } & Sign & Model 1 & Model 2 & Model 3 \\
\hline C & $?$ & $-2.100^{* * *}$ & $-2.198^{* * *}$ & $-2.337^{* * *}$ \\
RPT & + & $0.125^{* * *}$ & $0.122^{* * *}$ & -0.167 \\
BIG4 & - & $-0.052^{* * *}$ & $-0.052^{* * *}$ & $-0.051^{* * *}$ \\
FIRM SIZE & - & $0.127^{* * *}$ & $0.131^{* * *}$ & $0.142^{* * *}$ \\
LEVERAGE & + & 0.181 & 0.159 & 0.111 \\
LOSS & + & $0.029^{* * *}$ & $0.028^{* * *}$ & $0.028^{* * *}$ \\
ROA & + & $1.007^{* * *}$ & $1.003^{* * *}$ & $1.119^{* * *}$ \\
FAMILY & $+/-$ & & $0.090^{*}$ & 0.057 \\
RPT*FAMILY & $+/-$ & & & $0.325^{* *}$ \\
& & & & \\
R-squared & & 0.957 & 0.955 & 0.902 \\
Adjusted R-squared & & 0.930 & 0.925 & 0.836 \\
F-statistic & & 35.450 & 32.276 & 13.520 \\
Prob(F-statistic) & & 0.000 & 0.000 & 0.000 \\
N (Observations) & & 102 & 102 & 102 \\
\hline Nots: & & & & \\
\hline
\end{tabular}

Notes: ${ }^{*},{ }^{* *}$ and ${ }^{* * *}$ indicate significance at $1 \%, 5 \%$ and $10 \%$, respectively; DAC $=$ Accruals earnings management; $\mathrm{RPT}=$ Related Part Transactions; FAMILY = Family ownership structures; BIG4 = Audit firm; FIRM SIZE = company's size; LEVERAGE = company's ability to cover debt owned by assets; LOSS = company's earnings; $\mathrm{ROA}=$ the level of company profitability.

Regression model 2 shows that the family ownership structure has a positive effect on accrual earnings management. It means that the family ownership structure with share capital ownership above $20 \%$ can influence earnings management practices in Indonesia's consumer goods companies and support hypothesis 2. It indicates whether there are transactions with related parties carried out by these companies, family ownership is still able to influence the company's earnings management practices. Kumala \& Siregar (2020) stated that family ownership could influence the level of profit manipulation and provide an entrenchment effect that can expropriate the wealth of minority shareholders for their gain.

In the interaction variable between related party transactions and family ownership (RPT*FAMILY), the results show that this interaction strengthens the effect of related party transactions on management and supports hypothesis 3 . This moderation result is contrary to previous research conducted by Haji-Abdullah \& Wan-Hussin (2015). It showed that family ownership in Malaysia weakens the relationship of related party transactions with earnings management. However, the existence of a family as a shareholder who has control over the management of the company can encourage transactions with related parties that are detrimental (asset transfer or tunneling), which has an impact on the company's declining performance (Johnson et al., 2000; Mohammed, 2019).

A public accounting firm that audits the company's financial statements, which are derived from BIG4, company size (FIRM SIZE), company losses (LOSS), and company profitability ratio (ROA), individually affect earnings management. On the other hand, leverage individually does not significantly affect the company's level of earnings management practices. 


\section{DISCUSSION}

The purpose of this study is to examine the effect of transactions with related parties on earnings management carried out by companies, especially consumer goods companies in Indonesia, which are considered to have more ability to manage their company's operational activities than other manufacturing subsectors. The results show that the related party transactions significantly positively affected earnings management practices in Indonesia. The related party transactions that are carried out are more likely to lead to abusive transactions that improve earnings management practices. Related party transactions are carried out by the company abusively for the company's benefit, without paying attention to the impact that may be detrimental to minority shareholders. In line with research conducted by Rahmat et al. (2020), related party transactions are used opportunistically by controlling shareholders to manipulate earnings on an accrual basis, even more, because of low investor protection, thus reducing the quality of earnings generated by the company. Limanto \& Herusetya (2017) also state that manufacturing companies in Indonesia that have transactions with related parties higher than their total sales transactions have a close relationship with earnings management practices through their real activities.

The company's shareholders, who come from families, are increasingly abusing transactions with related parties. Family ownership is considered an entrenchment effect, which is detrimental to minority shareholders, in this case through company profits manipulation that does not reflect the actual conditions. According to Razzaque et al. (2016), family companies in Asia usually have low earnings quality with higher earnings management practices through accrual transactions than other countries, whose regulations are more stringent and disciplined.

\section{CONCLUSION, LIMITATIONS, AND SUGGESTIONS}

This study has limitations because it only focuses on companies providing consumer goods as a sample. The results obtained cannot be generalized to the manufacturing industry and other non-financial industries in Indonesia and other Asian countries with the same company characteristics in Indonesia. We suggest that the next research used a broader sample to be carried out to prove the effect of related party transactions on earnings management in more detail with more accurate data. Also, there are various types of models for the measurement of accrual earnings management, so it could be compared to find out the most appropriate one and has resulted in minimum bias. As well as the measurement of related party transactions, the influence of each type of transaction with related parties can be developed (Marchini et al., 2018b). This study extends the literature related to the effect of related party transactions by companies on earnings management. The influence of share capital owned by the family provides more control over the company's operational transactions, so it is relevant to conduct further research in other Asian countries with the same characteristics as Indonesia. 


\section{REFERENCES}

Aharony, J., Wang, J., \& Yuan, H. (2010). Tunneling as an incentive for earnings management during the IPO process in China. Journal of Accounting and Public Policy, 29(1), 1-26. https://doi.org/10.1016/j.jaccpubpol.2009.10.003

Alhadab, M., Abdullatif, M., \& Mansour, I. (2020). Related party transactions and earnings management in Jordan: The role of ownership structure. Journal of Financial Reporting and Accounting, 18(3), 505-531. https://doi.org/10.1108/JFRA-01-2019-0014

Avabruth, S. M., \& Saravanan, P. (2018). Earnings management preferences of family firms and its impact on the market value of the firm. SSRN Electronic Journal. https:// doi.org/10.2139/ssrn.3102030

Azizah, W. (2017). Opportunistic perspective off acrual adn real earnings management in Indonesia. IOSR Journal of Business and Management, 19(11), 1-5. https:// doi.org/10.9790/487X-1911070105

Chen, J. J., Chengb, P., \& Xiao, X. (2011). Related party transactions as a source of earnings management. Applied Financial Economics, 21(3), 165-181. https:/ / doi.org/10.1080/09603107.2010.528361

Chi, C. W., Hung, K., Cheng, H. W., \& Lieu, P. T. (2015). Family firms and earnings management in Taiwan: Influence of corporate governance. International Review of Economics and Finance, 36, 88-98. https://doi.org/10.1016/j.iref.2014.11.009

Dechow, P. M., \& Skinner, D. J. (2000). Earnings management: reconciling the views of accounting academics, practitioners, and regulators. Accounting Horizons, 14(2), 235250. https://doi.org/10.2308/acch.2000.14.2.235

Dechow, P. M., Sloan, R. G., \& Sweeney, A. P. (1995). Detecting earnings management. The Accounting Review, 70(2), 193-225. https:/ / doi.org/10.1002/9781119204763.ch4

El-Helaly, M. (2016). Related party transactions and accounting quality in Greece. International Journal of Accounting and Information Management, 24(4), 375-390. https:// doi.org/10.1108/IJAIM-04-2016-0044

El-Helaly, M. (2018). Related party Transactions: A Review of the Regulation, Governance and Auditing Literature. Managerial Auditing Journal, 33(8-9), 779-806. https:// doi.org/10.1108/MAJ-07-2017-1602

El-Helaly, M., Georgiou, I., \& Lowe, A. D. (2018). The interplay between related party transactions and earnings management: The role of audit quality. Journal of International Accounting, Auditing and Taxation, 32, 47-60. https://doi.org/10.1016/j.intaccaudtax.2018.07.003

Gordon, E. A., \& Henry, E. (2005). Related party transactions and earnings management. SSRN Electronic Journal. https://doi.org/10.2139/ssrn.612234

Habib, A., Muhammadi, A. H., \& Jiang, H. (2017). Political connections and related party transactions: Evidence from Indonesia. The International Journal of Accounting, 52(1), 4563. https://doi.org/10.1016/j.intacc.2017.01.004

Haji-Abdullah, N. M., \& Wan-Hussin, W. N. (2015). Related party transactions, audit committees and real earnings management: the moderating impact of family ownership. Advanced Science Letters, 21(6), 2033-2037. 
https:// doi.org/10.1166/asl.2015.6195

Hasnan, S., Daie, M. S., \& Hussain, A. R. M. (2016). Related party transactions and earnings quality: does corporate governance matter? International Journal of Economics and Management, 10(2), 189-219.

Healy, P. M., \& Wahlen, J. M. (1999). A review of the earnings management literature and its implications for standard setting. Accounting Horizons, 13(4), 365-383. https:// doi.org/10.2308/acch.1999.13.4.365

Jalan, A., Badrinath, S. G., \& Al-Gamrh, B. (2020). Women on audit committees and the relationship between related party transactions and earnings management. Strategic Change, 29(3), 389-406. https://doi.org/10.1002/jsc.2337

Jensen, M. C., \& Meckling, W. H. (1976). Theory of the firm: managerial behavior, agency costs and ownership structure. Journal of Financial Economics, 3(4), 305-360.

Johnson, S., La Porta, R., Lopez-de-Silanes, F., \& Shleifer, A. (2000). Tunneling. American Economic Review, 90(2), 22-27.

Kharista, M., Purnomosidhi, B., \& Subekti, I. (2020). The practice of expropriation through related party transactions In Indonesia. Jurnal Reviu Akuntansi Dan Keuangan, 10(2), 371-383. https:// doi.org/10.22219/jrak.v10i2.12214

Kuan, L., Tower, G., Rusmin, R., \& Van Der Zahn, J.-L. W. M. (2010). Related party transactions and earnings management. Jurnal Akuntansi Dan Auditing Indonesia, 14(2), 115-193.

Kumala, R., \& Siregar, S. V. (2020). Corporate social responsibility, family ownership and earnings management: the case of indonesia. Social Responsibility Journal. https:// doi.org/10.1108/SRJ-09-2016-0156

Limanto, G. K., \& Herusetya, A. (2017). The association between related party transactions and real earnings management: internal governance mechanism as moderating variables. SHS Web of Conferences, 34, 04008. https:// doi.org/10.1051/shsconf/20173404008

Lisboa, I. (2016). Impact of financial crisis and family control on earning management of portuguese listed firms. European Journal of Family Business, 6(2), 118-131. https:// doi.org/10.1016/j.ejfb.2017.06.002

Maigoshi, Z. S., Latif, R. A., \& Kamardin, H. (2016). Earnings management: A case of related party transactions. International Journal of Economics and Financial Issues, 6(7S), 51-55.

Marchini, P. L., Andrei, P., \& Medioli, A. (2019). Related party transactions disclosure and procedures: a critical analysis in business groups. Corporate Governance (Bingley), 19(6), 1253-1273. https:/ / doi.org/10.1108/CG-08-2018-0281

Marchini, P. L., Mazza, T., \& Medioli, A. (2018a). Related party transactions, corporate governance and earnings management. Corporate Governance: The International Journal of Business in Society, 18(6), 1124-1146. https:/ / doi.org/10.1108/CG-11-2017-0271

Marchini, P. L., Mazza, T., \& Medioli, A. (2018b). The impact of related party transactions on earnings management: some insights from the Italian context. Journal of Management and Governance, 22(4), 981-1014. https:/ / doi.org/10.1007/s10997-018-9415-y

Mardjono, E. S., Chen, Y.-S., \& He, L.-J. (2020). Earning management and the effect 
characteristics of audit committee, independent commissioners: Evidence from Indonesia. International Journal of Business and Society, 21(2), 569-587. https:// doi.org/10.5430/rwe.v11n3p108

Mita, A. F., \& Utama, S. (2015). The influence of corporate governance mechanism on the relationship between related party transactions and earnings management. International Research Journal of Business Studies, 7(1), 1-12. https:// doi.org/10.21632/irjbs.7.1.1-12

Mohammed, N. H. (2019). Related party transactions, family firm, and firm performance empirical evidence from Turkey. Accounting Analysis Journal, 8(3), 179-183. https:// doi.org/10.15294/aaj.v8i3.36665

Muda, I., Maulana, W., Siregar, H. S., \& Indra, N. (2018). The analysis of effects of good corporate governance on earnings management in Indonesia with panel data approach. Iranian Economic Review, 22(2), 599-625. https:// doi.org/10.22059/ier.2018.66169

Paiva, I. S., Lourenço, I. C., \& Branco, M. C. (2016). Earnings management in family firms: Current state of knowledge and opportunities for future research. Review of Accounting and Finance, 15(1), 85-100. https:/ / doi.org/10.1108/RAF-06-2014-0065

Paiva, I. S., Lourenço, I. C., \& Dias Curto, J. (2019). Earnings management in family versus non-family firms: the influence of analyst coverage. Spanish Journal of Finance and Accounting/Revista Espanola de Financiacion y Contabilidad, 48(2), 113-133. https:// doi.org/10.1080/02102412.2018.1463764

Penman, S. H. (2013). Financial Statement Analysis and Security Valuation (5th ed.). McGrawHill.

PwC. (2014). Survey bisnis keluarga 2014. In November (Issue November). https:// www.pwc.com/id/en/publications/assets/indonesia-report-familybusiness-survey-2014.pdf

Rahmat, M. M., Muniandy, B., \& Ahmed, K. (2020). Do related party transactions affect earnings quality? evidence from East Asia. International Journal of Accounting and Information Management, 28(1), 147-166. https:/ / doi.org/10.1108/IJAIM-12-2018-0146

Razzaque, R. M. R., Ali, M. J., \& Mather, P. R. (2016). Real earnings management in family firms: evidence from an emerging economy. Pacific-Basin Finance Journal, 40, 237-250. https:// doi.org/10.1016/j.pacfin.2015.12.005

Scott, W. R., \& O'Brien, P. C. (1997). Financial accounting theory (Vol.3. pp.). Upper Saddle River, NJ: Prentice hall.

Setiawan, D., Bandi, B., Kee Phua, L., \& Trinugroho, I. (2016). Ownership structure and dividend policy in Indonesia. Journal of Asia Business Studies, 10(3), 230-252. https:// doi.org/10.1108/JABS-05-2015-0053

Shan, Y. G. (2015). Value relevance, earnings management and corporate governance in China. Emerging Markets Review, 23, 186-207. https:// doi.org/10.1016/j.ememar.2015.04.009

Siregar, I. F., Roekhudin, R., \& Purwanti, L. (2018). Firm value predictor and the role of corporate social responsibility. Jurnal Keuangan Dan Perbankan, 22(3), 475-485. https:// doi.org/10.26905/jkdp.v22i3.1804 
Suprianto, E., \& Setiawan, D. (2018). Impact of family control on the relationship between earning management and future performance in Indonesia. Business and Economic Horizons (BEH), 14(2), 342-354. https://doi.org/10.15208/beh.2018.25

Suryani, A., Atikah, A., \& Putri, H. T. (2019). The effect of related party transactions through opportunistic behaviour management to increase firm value. J. Fin. Bank. Review, 4(2), 64-72. https://doi.org/10.35609/jfbr.2019.4.2(3)

Tai, Y. (2017). Earnings management in family firms : the role of inside directors. Jiao Da Guan Li Xue Bao, 37(1), 77-114.

Wong, R. M. K., Kim, J. B., \& Lo, A. W. Y. (2015). Are related-party sales value-adding or value-destroying? evidence from China. Journal of International Financial Management and Accounting, 26(1), 1-38. https://doi.org/10.1111/jifm.12023 